\title{
Using the Process-Genre Approach to Improve Fourth-Grade EFL Learners' Paragraph Writing
}

Usando el enfoque de proceso-género para mejorar la escritura de párrafos de los estudiantes de EFL de cuarto grado

Usando a Abordagem Processo-Gênero para Aperfeiçoar a Redação de Parágrafos de Estudantes de ESL do $4^{\circ}$ ano

Héctor Mauricio ARTEAGA-LARA

orcid.org/0000-000I-5765-6076.

FEM School, Montelíbano, Colombia.

harteaga@colfem.edu.co

$\begin{array}{ll}\text { Received: } 2018-01-11 & \text { Send to for peer review: 2018-01-12 } \\ \text { Accepted by peers: } 2018-01-23 & \text { Approved: 2018-03-07 }\end{array}$

To reference this article in APA style / Para citar este artículo en APA / Para citar este artigo Arteaga-Lara, H. M. (2017). Using the process-genre approach to improve fourth-grade EFL learners' paragraph writing. Latin American Journal of Content and Language Integrated Learning, 10(2), 217-244. doi: 10.5294/laclil.2017.10.2.3 
ABSTRACT. Writing plays a significant role in language learning. Previous research has reported on the effectiveness of several approaches to develop writing skills to enhance writing competence, but little attention has been given to the paragraph writing of elementary students. The present qualitative action research study used artifacts, teacher's journals, learner's journals, and a focus group interview to collect data on the way the process-genre approach assisted fourth-grade EFL learners in writing well-structured narrative paragraphs. Data were analyzed using the grounded theory approach, showing that most of the participants managed to write well-structured paragraphs in which they developed only one idea and supported it without deviating from the subject. Learners also became aware of the role of the audience and the features of the narrative writing genre. The findings of the study lend support to the notion that the process-genre approach is an effective way for young learners to achieve the expected goal; hence, it could be more widely adopted in writing courses at the elementary school level.

Keywords: Writing; paragraph writing; process-genre approach.

RESUMEN. La escritura juega un papel crucial en el aprendizaje de idiomas. Estudios previos han descubierto la efectividad que diversos enfoques tienen en el desarrollo de habilidades de escritura con el fin de optimizar la competencia escrita de los estudiantes; sin embargo, se le ha dado poca importancia a la escritura de párrafos en estudiantes de primaria. El presente estudio de investigación-acción se valió de artefactos, diario del docente, diario de los estudiantes y entrevista grupal para recolectar datos acerca de la manera en la que el enfoque de proceso y género ayudó a estudiantes de inglés como lengua extranjera en cuarto grado de primaria a escribir párrafos narrativos bien estructurados. Los datos fueron analizados a la luz de la teoría fundamentada, y revelaron que la mayoría de los participantes logró escribir párrafos narrativos bien estructurados en los que desarrollaron solo una idea principal sin desviarse del tema. Estos participantes, además, lograron concientizarse sobre el rol de la audiencia (los lectores) y las características del género narrativo de escritura. Todo esto justifica la noción de que el enfoque de proceso y género es un método efectivo para que los estudiantes de primaria alcancen el objetivo mencionado por lo cual podría ser adoptado por escuelas de primaria en sus cursos de escritura.

Palabras claves: escritura; escritura de párrafos; enfoque de proceso y género.

RESUMO. A escrita tem um papel significativo na aprendizagem de um idioma. Pesquisas anteriores mostraram a efetividade de diversas abordagens para desenvolver habilidades de redação para aperfeiçoar a competência escrita, mas pouca atenção é dada à redação de parágrafos de estudantes do ensino fundamental. O presente estudo de pesquisa de ação qualitativa usou recursos - registros de professores, diários de alunos e um grupo de referência - para coletar dados sobre a maneira em que a abordagem processo-gênero ajudou os estudantes de ESL do $4^{\circ}$ ano a escrever parágrafos narrativos bem estruturados. Os dados foram analisados utilizado a teoria fundamentada e mostram que a maioria dos participantes conseguiu escrever parágrafos bem estruturados nos quais desenvolveram uma única ideia e a sustentaram sem desviar do assunto. Os estudantes também se deram conta do papel do público e das características da redação do gênero narrativo. As descobertas do estudo corroboram a noção de que a abordagem processo-gênero é uma maneira efetiva para que jovens estudantes alcancem o objetivo esperado, então, poderia ser mais vastamente adotada em cursos de redação em escolas de nível fundamental.

Palavras-chave: abordagem processo-gênero; escrita de parágrafo; redação. 


\section{Introduction}

Writing is a communicative process, one of the four language skills along with reading, listening and speaking (Hinkel, 2006). Furthermore, it is classified as one of the "productive skills" that lead to language production because it is one of "the processes involved in creating and expressing meaning" (Richards \& Schmidt, 2002, p. 292). Writing as a process implies several stages; more specifically, it is "viewed as the result of complex processes of planning, drafting, reviewing and revising" (Richards \& Schmidt, 2002, p. 592). Thus, it is a skill that demands attention to the steps connected to communicative purposes.

Writing can be considered communicatively by means of the process-genre approach (Badger \& White, 2000). On the one hand, the process approach is commonly known as the view that focuses on the writer's potential skills to perform writing. Tribble (1996) defined this process as "a cycle of writing activities which move learners from the generation of ideas and the collection of data to the 'publication' of a finished text" (p. 37); this approach is designed to bring about writing skills in learners and to strengthen them. On the other hand, genre approach focuses on the reader or the audience to which the text is addressed. It means the writer must select several features (e.g., vocabulary, functions, discourse, style, etc.) and consider who the reader is (e.g., friends, parents, professionals, etc.). In other words, the writer must interact with the reader by setting a purpose to the writing and making it understandable. It is a social activity in which both parties (writer-reader) communicate through the channel of a text. The process-genre approach incorporates the salient points of the mentioned approaches and thus accounts for writing as a communicative process. This approach was chosen as the strategy to tackle the task of learning to write paragraphs - the core of this study-in the context of fourthgrade EFL learners at a private school in Chía, Colombia.

Previous studies on writing have examined the effect of process and genre approaches on the improvement of the writing competence both in young and adult learners. Process approach has been studied as to the benefits it brings to writing. Firstly, this approach helped participants to develop and use planning and organization strategies 
throughout the stages of the process, which fostered their writing skills (Badiaa, 2016; Bueno Hernández, 2016; Gashout, 2014; Susser, 1994). Secondly, the use of this approach was shown to afford students the opportunity of interacting with different aspects of writing, such as generating and discovering ideas collaboratively, exposing them to different views, and giving and receiving immediate feedback on language to make writing more accurate and appropriate (Fernández Dobao, 2012; Rodríguez Espinosa, 2014; Storch, 2005, 2011; Yate González, Saenz, Bermeo, \& Castañeda Cháves, 2013). Finally, the process approach helped participants to improve their writing continuously by evaluating them several times and developing, at the same time, thinking strategies such as noticing and explaining when identifying mistakes (Alodwan \& Ibnian, 2014; Bayat, 2014; Díaz Galvis, 2010). This approach, however, shows a limited view of different kinds of texts and their characteristics, leading therefore to little awareness of the variety of writing styles and little or no communicative purpose related to audience (Horowitz, 1986; Porto, 2001).

Regarding the genre approach, some significant studies have been carried out for several purposes, as cited herein. These studies implemented genre-based pedagogy using specific written genres as the basis of the teaching plan for their population. The researchers concluded that genre approach can be an effective way of teaching writing to students, for it clearly helped them to organize their writing with a sense of audience (i.e. awareness of who the reader is) and understand the nature of a text and the ways genres interact to fulfill social purposes (Dirgeyasa, 2016; Elshirbini, 2013; Hyland, 2003, 2007; Yang, 2016). It also helped participants enhance their writing abilities in content, organization, vocabulary, and language use within specific contexts and for different purposes (Ahn, 2012; Chen \& Su, 2012; Firkins, Forey, \& Sengupta, 2007). Finally, this genre pedagogy provided participants with useful models for both organizing and assessing their writings (Lee, 2012; Setyowati \& Widiati, 2014). It is clear the positive effect that genre approach has on the teaching and learning of writing; however, this approach presents a limitation in regards to the practice of varied writing strategies within a process for they basically follow models and become aware of their characteristics to be replicated (Elshirbini, 2013). 
Finally, some studies related to the process-genre approach and to the development of writing skills were conducted for several purposes as cited herein. This approach helped participants to develop strategies throughout the stages of the writing process connected to a purpose and audience, and offered them the opportunity to follow some writing steps to analyze the text models as a guide for their own writing and to write for a real communicative purpose (Garnica Olaya \& Torres Burbano, 2015; Rusinovci, 2015; Voon Foo, 2007). The participants also improved clarity of ideas, essay structure, and features of specific genres such as descriptive texts, among others; for they had to integrate language, context knowledge and the writing process addressed to a purpose, audience and social context (Babalola, 2012; Tuyen, Osman, Dan, \& Ahmad, 2016). In this sense, participants developed the skill to convey their ideas, especially to support the communicative purpose of the writing task (Handayani \& Siregar, 2013). Participants played the role of planners, builders and reviewers of their own writings, having the features of genre as a constant reference to comply with their roles successfully (Cuesta \& Rincón, 2010). Participants, finally, were greatly exposed to several language inputs which gave them wider understanding about writing genres within communicative contexts (Chang \& Szanajda, 2016). The aforementioned studies support the present research, showing that process and genre approaches do enhance learners' writing competence related to genre and audience awareness and that they promote their writing skills.

In this sense, the present study intended to implement the process-genre approach with fourth-grade learners to identify its effect in their learning of paragraph writing. Even though the previously mentioned studies showed the implementation of process and genre approaches in different contexts, a search of the literature found no studies that referred specifically to the process-genre approach used with fourth-grade learners focused on writing well-structured narrative paragraphs. Accordingly, the present study's objective was "to identify what happens to paragraph writing and participants' writing skills when the process-genre approach is used with fourth-grade EFL learners," and the corresponding research question was "How does the use of process-genre approach help fourth-grade EFL learners write well-structured paragraphs?". 


\section{Method}

This study was designed under parameters of qualitative action research (Greenwood, 1999, p. 32) carried out by means of four specific and flexible steps: planning, action, observation, and reflection (Burns, 2010). It was conducted at a bilingual private school in Chía, Colombia, with a group of 13 fourth-grade learners: seven boys and six girls. Their ages ranged between 9 and 10 years old. Since they were kids, the present study followed the ethical considerations required to inform the direct and indirect participants (i.e., learners and their parents, respectively) about its nature, process, intention and objectives. For this reason, two consent letters were sent to call upon voluntary and conscious participation. Firstly, one letter was addressed to the school principal in order to let them know about the main aspects of the study and to obtain official permission. Secondly, one letter was addressed to the learners' parents in order to inform them about the study and obtain their consent to let their children participate.

These learners were in the transition from A1 to A2 according to the CEFR (Council of Europe, 2001); however, their receptive skills (listening and reading) were much more developed than their productive ones (speaking and writing), as they had been exposed to intensive input in English language since preschool but had not been required to produce this language as intensively. With regard to English language lessons for the primary levels-that is, students from second to fifth grade-, the school has established nine 40-minute lessons per week, distributed as follows: Language (5 lessons), Reading and Writing (2 lessons), Oral English (1 lesson), and Phonics (1 lesson). Apart from this, primary students are exposed to content subjects, since the school offers Science and Math in English.

Related to writing, the participants use literal translation as the main strategy to produce written language. This is the method they have at hand, and they find it easy to follow. Consequently, these learners commonly experience L1 interference as the basis of their lexical choice and sentence structure in the L2 writing (O'Malley \& Chamot, 1990). Apart from this, the organization of ideas is not clearly evidenced in their writings; they normally write what comes to their mind 
without a specific order. For this reason, these learners needed to be exposed to a new set of strategies to work on paragraph writing developing only one idea without deviating from the topic and organizing the information coherently.

The strategy selected to address the problem was the process-genre approach, for it deals with the learning of writing as a communicative process. This approach, proposed by Badger and White (2000), highlights the aims of process and genre approaches to writing. Process approach focuses on linguistic skills, such as in the stages of prewriting, composing, revising/editing and publishing (Tribble, 1996). As for genre approach, writing is a linguistic product influenced by a context and purpose and follows three stages, in which "first, a model of a particular genre is introduced and analyzed. Learners then carry out exercises which manipulate relevant language forms and, finally, produce a short text" (Badger \& White, 2000, p. 156). Genre approach sheds light in this study by stating that linguistic features are not relevant per se within a text; instead, they are informed for a social purpose. In other words, "genre theory seeks to understand the ways individuals use language to orient to and interpret particular communicative situations" (Hyland, 2003, p. 22). Given the features of these approaches, the intention of Badger and White (2000) was to propose their unification under the term process-genre, which "sees writing as a series of stages leading from a particular situation to a text, with the teachers facilitating learners' progress by enabling appropriate input of knowledge and skills" (Badger \& White, 2000, p. 160). Hence, the process-genre approach tackles the learning of writing considering the context and the process required to write effectively. Concretely, participants used this approach to write a 150-word narrative paragraph about a personal experience. Never had they been encouraged to use such approach, nor been asked to write a structured paragraph (topic sentence, supporting ideas and concluding sentence).

The lesson plans in the pedagogical implementation were carried out following established stages-specifically, warm-up, presentation, guided and free practice, self-assessment, and self-reflection. These lesson plans promoted interaction patterns based on learner-centered pedagogy and collaborative work. The classroom was organized in three small groups where learners were randomly placed every week; 
for these reasons, the interaction patterns were often referred to as Ss - Ss / S - Ss (i.e., group work and from individual to group work, respectively) and the group work or group sharing normally took place among the students within a small group.

Each session was carried out during several lessons at the school where the study/implementation took place. Each session had a corresponding workshop designed as a whole unit which had common characteristics such as name/topic of the session; general and specific objectives; an image synthesizing the topic; written instructions for each activity, which learners in each group had to read and follow; a self-assessment worksheet with "I can" statements and examples to be given; and the learner's journal related to the corresponding session and, ultimately, to the course in general (the implementation). Learners became familiar with the workshops and worked on them as a learning routine, moving from individual to pair or group work, helping each other when necessary and sharing and comparing their work to achieve the goal of every task.

The pedagogical implementation of the present study consisted of six sessions of four hours each and an introductory session, as illustrated in Table 1.

Table 1. Implementation stages

General Aim: By the end of the course, learners will have written a 150word narrative paragraph including topic sentence, three supporting ideas and a concluding sentence about either a funny, scary, embarrassing or a memorable experience in their lives.

\begin{tabular}{|l|l|l|l|}
\hline Session & \multicolumn{1}{|c|}{ Topic } & \multicolumn{1}{c|}{ Aim } & Duration \\
\hline $\begin{array}{l}\text { Intro } \\
\text { Session }\end{array}$ & $\begin{array}{l}\text { The writing } \\
\text { course }\end{array}$ & $\begin{array}{l}\text { To acquaint learners with the course } \\
\text { objective, to choose the personal } \\
\text { experience to write, and to pilot the } \\
\text { learner's journal }\end{array}$ & 2 hours \\
\hline Session 1 & Prewriting 1 & $\begin{array}{l}\text { To identify the structure and the } \\
\text { language used in a narrative } \\
\text { paragraph }\end{array}$ & 4 hours \\
\hline Session 2 & Prewriting 2 & $\begin{array}{l}\text { To use three strategies to plan the } \\
\text { writing of a personal experience in a } \\
\text { narrative paragraph }\end{array}$ & 4 hours \\
\hline
\end{tabular}




\begin{tabular}{|c|c|c|c|}
\hline Session 3 & $\begin{array}{l}\text { Drafting \& } \\
\text { Revising }\end{array}$ & $\begin{array}{l}\text { To write the first draft of the narrative } \\
\text { paragraph following the structure } \\
\text { previously established. } \\
\text { To self- and peer-revise the drafts } \\
\text { focusing on language and structure }\end{array}$ & 4 hours \\
\hline Session 4 & $\begin{array}{l}\text { Editing \& } \\
\text { Publishing }\end{array}$ & $\begin{array}{l}\text { To write the final version of the } \\
\text { narrative paragraph based on prior } \\
\text { edition. }\end{array}$ & 4 hours \\
\hline Session 5 & $\begin{array}{l}\text { Assessment } \\
\text { \& Feedback }\end{array}$ & $\begin{array}{l}\text { To socialise the narrative paragraphs } \\
\text { and to provide written peer and } \\
\text { teacher's feedback. }\end{array}$ & 4 hours \\
\hline Session 6 & $\begin{array}{l}\text { Putting it all } \\
\text { together }\end{array}$ & $\begin{array}{l}\text { To write another narrative paragraph } \\
\text { following the process to write in less } \\
\text { time. }\end{array}$ & 4 hours \\
\hline
\end{tabular}

Source: Own elaboration.

To collect data, the researcher designed and validated four instruments, namely the teacher's (the researcher) journal, which is meant to keep a continuous record of the activities carried out in every lesson, describing what happened in class. A learner's journal, aimed at collecting information about the participant's perceptions regarding the tasks/sessions; artifacts (the paragraphs), which is an effective way of collecting data related to the participants' sequential work throughout the setting of the action research. A focus group interview in Spanish, which is an instrument that allows the teacher/observer to check on students/participants' thoughts and perceptions regarding specific aspects of what has been done, in this case the research implementation. These instruments were designed to gather information related to the participants' production, behavior, and their perceptions about the methodology and strategy used to write paragraphs. In the case of learner's journal, taking the participants' age into consideration (9-10), the learners were given cues in every session to guide each entry with simple questions related to what they learned, clarity of topics and difficulties; they were also given the chance to write in this journal using Spanish or Englishm as per their choice.

At the end of every session, data was collected from both the teacher's (the researcher) and learner's journals. The artifacts were collected in the corresponding sessions and, at the end, after session 6, learners 
were interviewed in small groups to collect their final perception on the course (focus group interview).

The data analysis was carried out following the stages of the grounded theory method. Grounded theory refers to a method that builds "theoretical constructs derived from qualitative analysis of data" (Corbin \& Strauss, 2008, p. 1). The focus of this method lies mainly in coding the collected data by identifying and giving name to small pieces or segments, defined as "text that is comprehensible by itself and contains one idea, episode, or piece of relevant information" (McMillan \& Schumacher, 2010, p. 370). In the present study, this coding process was carried out by organizing the collected data from the instruments (teacher's journal, learner's journals, a focus group interview in Spanish, and artifacts), identifying segments to be analyzed and coded, triangulating the data to integrate codes into categories and, finally, interconnecting categories to determine the core category, which answered the research question.

\section{Results}

In the process of coding the collected data, two categories, four subcategories and one core category were developed (Figure 1). The artifacts (the paragraphs) served as evidence to support these categories.

Figure 1. Final categories, subcategories, and core category

\begin{tabular}{|l|l|l|}
\hline \multirow{5}{*}{$\begin{array}{l}\text { Categories and } \\
\text { subcategories }\end{array}$} & $\begin{array}{l}\text { 1. The process-genre } \\
\text { approach as a way of } \\
\text { enhancing learners' writing } \\
\text { skills }\end{array}$ & $\begin{array}{l}\text { Process-genre approach } \\
\text { to write better }\end{array}$ \\
\cline { 2 - 3 } & $\begin{array}{l}\text { Learners' awareness of } \\
\text { "edition" as the bridge } \\
\text { between draft and final } \\
\text { version }\end{array}$ \\
\cline { 2 - 3 } & $\begin{array}{l}\text { 2. Learners' strengths and } \\
\text { weaknesses in writing } \\
\text { well-structured narrative } \\
\text { paragraphs }\end{array}$ & $\begin{array}{l}\text { Learners' realization } \\
\text { of narrative paragraph } \\
\text { structure }\end{array}$ \\
\cline { 3 - 3 } & $\begin{array}{l}\text { Difficulties with narrative } \\
\text { paragraph structure }\end{array}$ \\
\hline
\end{tabular}




\begin{tabular}{|l|l|l|}
\hline Core category & $\begin{array}{l}\text { The process-genre approach } \\
\text { helped most of fourth-grade } \\
\text { EFL learners develop specific } \\
\text { writing skills, which they used } \\
\text { to plan, organize and revise } \\
\text { structure in their paragraphs } \\
\text { based on narratives. }\end{array}$ & \\
\hline
\end{tabular}

Source: Own elaboration.

\section{The process-genre approach as a way of enhancing learner's writing skills}

The implementation of the process-genre approach to write well-structured paragraphs provided fourth-grade EFL learners with opportunities to enhance their writing skills in the stages of the mentioned approach: prewriting (analyzing writing samples of personal narratives, and planning their writing), drafting, revising/editing (based on checklists from writing models of personal narratives), and, finally publishing. This was the first time participants were exposed to such writing approach which, based on the collected data, proved to be an effective way of helping them foster their skills to use the written language (Badger \& White, 2000).

\section{Process-genre approach to write better}

Participants realized their writing skills improved throughout the implementation of the process-genre approach by following a process to write, by following models of personal narratives and by using writing strategies to write their own narrative paragraphs.

Participants worked on writing their personal narrative paragraph following the process-genre approach, which, in the end, helped them raise consciousness on the need of following a process when pursuing good writing products (Badger \& White, 2000; Tribble, 1996). Simultaneously, they managed to compare how they used to write and the way this process helped them write; for instance, they used to write their ideas as they came without following a specific structure. However, after this process they would consider organization patterns to write (e.g., main idea and supporting ideas) and, above all, they would revise and edit their writing. This perception was evidenced in Excerpt 1. 
Excerpt 1. Translated from focus group interview

Interviewer: How do you think the writing process can help you write better?

P4: "This can help us, say, like not to write a paragraph and leave it untouched; we have to follow a process to make it better with good writing."

P13: "If we follow the process step by step, we can have better results because we will get clear what we must write."

This excerpt shows how participants could reflect on the benefits of following a process to write; in this case, the process-genre approach brings about positive changes in their writing performance, for this process gave them time and tools to plan, write, assess, revise, edit and evaluate their written work.

Secondly, participants became aware of the fact that there are features and readers to be considered when writing a specific genre (Byrne, 1993; Hyland, 2009), in this case, personal narratives. They were exposed to narrative features and structure in the prewriting stage of the process-genre approach; most of them identified these features/structure and attempted to use them as a model in specific exercises (see Excerpt 2) and later in their paragraphs (draft and definitive version).

Excerpt 2. Taken from Participant 3, workshop session 1

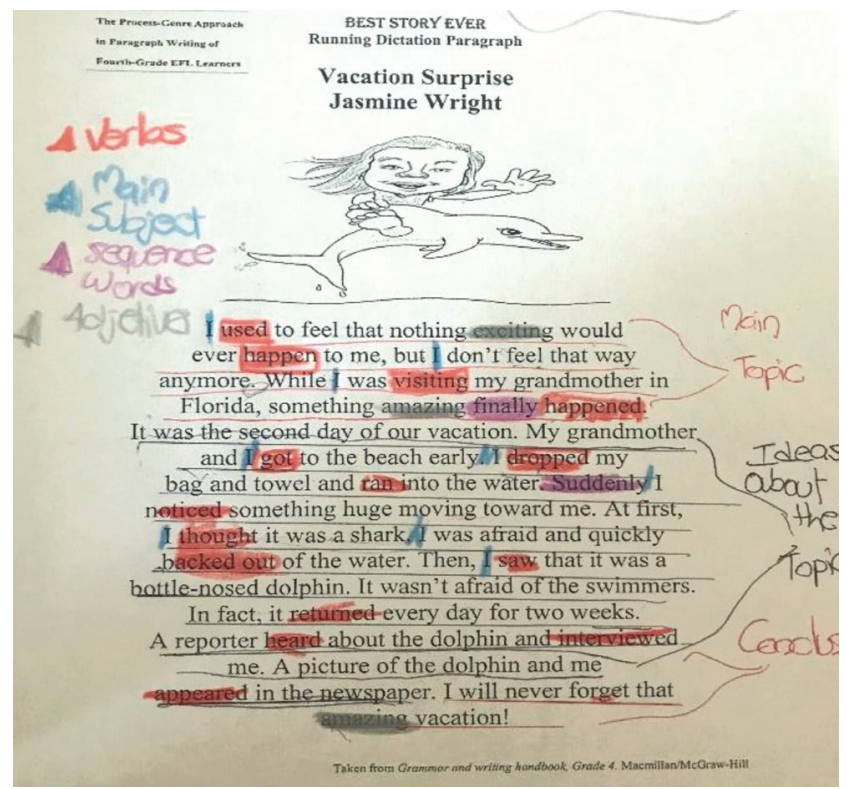


This excerpt shows how the participant used colors to identify features of narratives and to identify parts of the paragraph as main topic, ideas about the topic, and conclusion. Although not all the participants worked at the same level, most of them succeeded in such enterprise as evidenced in Excerpt 3.

Excerpt 3. Teacher's journal

"[Participants] they easily identified the main features of narrative paragraphs. Regarding language features of personal narratives (personal pronoun I/we, past verbs, adjectives to express emotions and time-order words), they expressed it was clear and easy to identify."

Participants, apart from learning about paragraph structure and narrative features, realized the importance of considering the reader as the measure of clarity and accuracy when writing (Hyland, 2009); in other words, they became aware of the reader as the social dimension of writing (see Excerpt 4).

Excerpt 4. Translated from focus group interview

\section{Interviewer: How did you find the writing course workshops? Explain}

P6: "As for me, the workshops help me write good stories so that people do not get bored when reading them."

\section{Interviewer: How do you think the writing process can help you write better?}

P1: "I think this can help me write better because when we write a paragraph it has to be very well-written for people to understand it; so when we write well and understandable, we learn that we can write better than we already do."

This aspect gave participants a sense of purpose for writing well, for using clear language and structure and for making their narrative paragraph a serious and, at the same time, entertaining evidence of their personal experience; all these aspects carry along an ultimate social function instead of being a mere academic endeavor (Hyland, 2007; Tribble, 1996).

Finally, participants used a variety of writing strategies to work on their personal narrative paragraphs throughout the stages of the 
process-genre approach. Some of the mentioned strategies were color-coding in the prewriting stage, used to identify and classify narrative features/structure. Other strategies were: brainstorming, Wh-questions" to guide brainstorming and mind mapping in the planning stage (prewriting); story mapping to organize their ideas into a structure (bridge between prewriting and drafting); peer correction based on writing checklist and color-coding to identify writing mistakes in the revising/editing stage; and finally, self-edition based on peer-assessment following a writing rubric in the publishing stage.

\section{Learners' awareness of "edition" as the bridge between draft and definitive version}

Strongly connected to the previous findings, participants became aware of the usefulness of the writing process, especially in the stage of revision/edition, which they found meaningful and enjoyable, when they compared their writings to good narrative models and correct them based on a narrative writing checklist. This validated the effectiveness of using comparison of standards in scaffolding writing practices by means of models. This stage made participants realize that a draft is not a definitive version and that they normally submit their written assignments with the characteristics of a draft instead of a final version.

One the one hand, participants became aware of their own writing limitations related to language and the processes they follow. They agreed that they often made mistakes when writing and that they needed to pay more attention to them while writing and after doing it as evidenced in Excerpt 5.

Excerpt 5. Translated from focus group interview

Interviewer: Do you perceive any change in your writing after the writing course? (How was it before and now?)

P6: "I did not use to include punctuation and did not use to consider capital letters at the beginning of a new sentence or in proper nouns; however, this process to write helped me check what was incorrect." 
The process-genre approach in the stage of revising/editing helped participants develop and enhance the skill of correcting writing, which requires language awareness (e.g., grammar, spelling, punctuation, and capitalization) in order to do it (Bolitho et al., 2003; Harmer, 2004).

On the other hand, participants agreed on the usefulness of writing correction based on a personal narrative checklist and became aware of the role this aspect plays within the writing process in order to self- and peer-correct (Harmer, 2004). To this end, they used several strategies such as color-coding to identify mistakes (see Excerpt 6), self/peer correction based on narrative checklist and peer-assessment based on a writing rubric.

\section{Excerpt 6. Taken from Participant 13, workshop session 4}

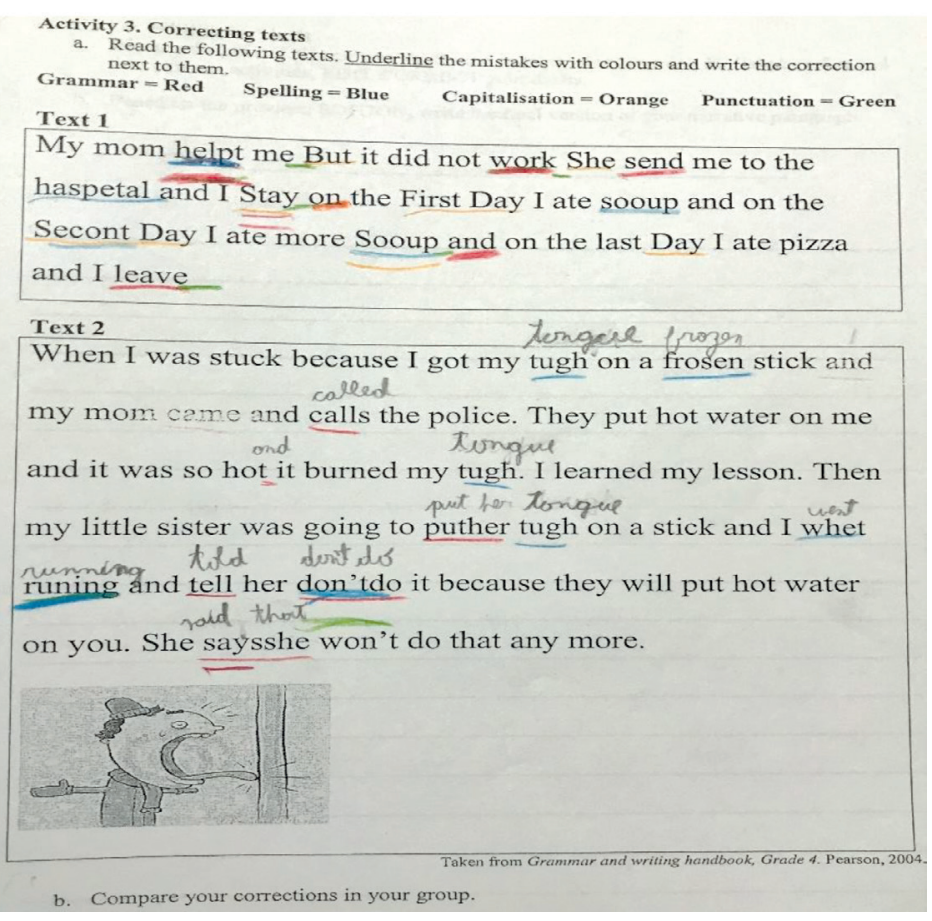

Participants devoted a great deal of time correcting their and others' writings, using the strategies previously mentioned, and they expressed they enjoyed doing this. It required knowledge about the language for which they claimed to be learning more about English. Based on that knowledge, it was necessary to establish criteria to correct writing related to grammar, spelling, punctuation, and capitalization. 
Participants were exposed to some input in this regard at the beginning of the revising/editing stage in the process-genre approach, and they were also asked to pay attention, when correcting, whether the paragraph structure was present and clear (i.e., topic sentence, supporting ideas, and concluding sentence).

All participants expressed writing correction was useful and entertaining; however, some of them did not work on this aspect as thoroughly as others did, for they simply underlined few words more as a way of complying with the task. Although there was significant improvement from the paragraph drafts to the final versions as presented in Table 2, some of them looked almost the same, which means some participants were not as committed to the edition task and considered their paragraphs were already edited with the first revision. This has to do with the fact that learners in our Colombian context are generally not used to revising and editing when writing and they wait until their teacher tells them what and how to correct their writing.

Table 2. Tally sheet based on rubric for paragraph assessment

\begin{tabular}{|c|c|c|c|c|c|c|}
\hline $\begin{array}{c}\text { Number of } \\
\text { paragraphs that } \\
\text { meet the mentioned } \\
\text { criteria }\end{array}$ & Excellent & Good & Poor & Excellent & Good & Poor \\
\cline { 2 - 7 } & 4 & 6 & 3 & 5 & 5 & 3 \\
\hline Topic sentence & 4 & 9 & 0 & 8 & 5 & 0 \\
\hline Supporting ideas & 0 & 4 & 9 & 2 & 4 & 7 \\
\hline $\begin{array}{c}\text { Concluding } \\
\text { sentence }\end{array}$ & 3 & 6 & 4 & 6 & 3 & 4 \\
\hline $\begin{array}{c}\text { Organisation \& } \\
\text { cohesion }\end{array}$ & 0 & 2 & 11 & 2 & 5 & 6 \\
\hline Conventions & & & & & & \\
\hline
\end{tabular}

Source: Own elaboration.

\section{Learners' strengths and weaknesses in writing well-structured nar- rative paragraphs}

Participants used the process-genre approach to write a 150-word narrative paragraph about a personal experience. It was the first time they were to use such approach and the first time they were asked to write 
a structured paragraph (topic sentence, supporting ideas, and concluding sentence). To this end, they followed the steps of the process-genre approach, namely, prewriting (analyzing narratives and planning their paragraphs), drafting, revising/editing (based on narratives checklist) and publishing. Three artifacts were the result of this process (i.e., paragraph draft, final version and extra version which was written in a shorter period of time), which were assessed by means of a rubric focused especially on paragraph structure, cohesion and conventions, as shown in Table 3. These artifacts, therefore, supported the findings related to learners' strengths and weaknesses in writing well-structured narrative paragraphs by using the process-genre approach.

Table 3. Rubric for paragraph assessment

\begin{tabular}{|c|c|c|c|}
\hline CATEGORY & 3 & 2 & 1 \\
\hline $\begin{array}{l}\text { Topic } \\
\text { Sentence }\end{array}$ & $\begin{array}{l}\text { Begins the } \\
\text { paragraph with } \\
\text { a topic sentence } \\
\text { that expresses } \\
\text { the main idea } \\
\text { according to the } \\
\text { task requirement }\end{array}$ & $\begin{array}{l}\text { Begins the } \\
\text { paragraph with a } \\
\text { topic sentence that } \\
\text { vaguely expresses } \\
\text { the main idea } \\
\text { according to the } \\
\text { task requirement }\end{array}$ & $\begin{array}{l}\text { Does not begin the } \\
\text { paragraph with a } \\
\text { topic sentence }\end{array}$ \\
\hline $\begin{array}{l}\text { Supporting } \\
\text { Ideas }\end{array}$ & $\begin{array}{l}\text { Writes at least } \\
3 \text { details that } \\
\text { support the main } \\
\text { idea coherently }\end{array}$ & $\begin{array}{l}\text { Writes details that } \\
\text { vaguely support } \\
\text { the main idea }\end{array}$ & $\begin{array}{l}\text { Does not write } \\
\text { details that } \\
\text { support the main } \\
\text { idea }\end{array}$ \\
\hline $\begin{array}{l}\text { Concluding } \\
\text { Sentence }\end{array}$ & $\begin{array}{l}\text { Concludes the } \\
\text { paragraph with a } \\
\text { sentence strongly } \\
\text { connected to the } \\
\text { main idea }\end{array}$ & $\begin{array}{l}\text { Concludes the } \\
\text { paragraph with a } \\
\text { sentence vaguely } \\
\text { connected to the } \\
\text { main idea }\end{array}$ & $\begin{array}{l}\text { Does not conclude } \\
\text { the paragraph } \\
\text { with a sentence } \\
\text { connected to the } \\
\text { main idea }\end{array}$ \\
\hline $\begin{array}{l}\text { Organisation } \\
\& \text { Cohesion }\end{array}$ & $\begin{array}{l}\text { Uses order words } \\
\text { such as first, } \\
\text { then, after, finally } \\
\text { to organise the } \\
\text { writing and make it } \\
\text { flow smoothly }\end{array}$ & $\begin{array}{l}\text { Inconsistently uses } \\
\text { order words such } \\
\text { as first, then, after, } \\
\text { finally to organise } \\
\text { the writing }\end{array}$ & $\begin{array}{l}\text { Does not use } \\
\text { any order words } \\
\text { to organise the } \\
\text { writing and make it } \\
\text { flow smoothly }\end{array}$ \\
\hline Conventions & $\begin{array}{l}\text { Very good } \\
\text { spelling, grammar, } \\
\text { punctuation and } \\
\text { capitalisation }\end{array}$ & $\begin{array}{l}\text { Few mistakes in } \\
\text { spelling, grammar, } \\
\text { punctuation and } \\
\text { capitalisation }\end{array}$ & $\begin{array}{l}\text { Too many } \\
\text { mistakes in } \\
\text { spelling, grammar, } \\
\text { punctuation and } \\
\text { capitalisation }\end{array}$ \\
\hline
\end{tabular}


This rubric was designed and validated at university by the researcher for assessing the participants' paragraphs according to the main requirements of paragraph structure (topic sentence, supporting ideas, and concluding sentence), coherence and cohesion, and correction of mistakes, along a continuum with column 3 rating as excellent achievement and column 1 as poor.

\section{Learners' realization of narrative paragraph structure}

Participants became aware of the narrative paragraph structure (i.e., topic sentence, supporting ideas and concluding sentence), which is intertwined with the narrative features and cohesive devices (e.g., time-order words such as first, then, etc.). They worked on these aspects since the beginning of the implementation-more specifically in the prewriting stage.

In this regard, the process-genre approach provided participants with opportunities to identify such paragraph structure, to understand how it works and to use it in exercises, which they attempted to replicate in their own paragraphs. To this end, they used the previously mentioned strategies provided by the process-genre approach from the prewriting to the publishing stages, which made most of their paragraphs look well-structured regardless of language mistakes present in those paragraphs. Some of these artifacts (Excerpt 7) served as evidence to demonstrate the previous statement.

Excerpt 7. Artifacts: draft, final version and extra paragraph, Participant 1

\begin{tabular}{|l|l|}
\hline \multicolumn{1}{|c|}{ P1 } & \multicolumn{1}{|c|}{$\begin{array}{c}\text { Researcher's } \\
\text { comments }\end{array}$} \\
\hline $\begin{array}{l}\text { when I went usa the day I went to usa was the best day of my } \\
\text { life... first I went to miami, I feel very happy and I was so scare } \\
\text { because I didnt know how talk english, but yes, that was my } \\
\text { dream when I have 7 years old. 5 or 7 days later I went to orlando } \\
\text { and I felt very good because I went to a lot of parts like universal, } \\
\text { that was fantastic because in that park I saw a lot of funny things. } \\
\text { I felt exiting because I saw the actors of the movie "Transformers" } \\
\text { and at that time I like that movie a lot, but, that was not the best, } \\
\text { the best was when I went to disney in orlando and I saw imicky } \\
\text { mouse!, that was my dream at that time, because in that time, I all } \\
\text { time saw the program micky mouse and also I saw minnie and all } \\
\text { them. then, } 5 \text { of 8 day later, I went to new york and I saw and went } \\
\text { to the famous empire state, and I learn that in the empire state was } \\
\text { recorted the movie "king kong". finally I learn a lot of things and I } \\
\text { come the main idea. Weak } \\
\text { concluding sentence } \\
\text { for it does not refer to } \\
\text { the main topic. There } \\
\text { are several errors } \\
\text { mainly related to } \\
\text { capitalisation. }\end{array}$ \\
\hline
\end{tabular}




\begin{tabular}{|c|c|}
\hline P1 & $\begin{array}{l}\text { Researcher's } \\
\text { comments }\end{array}$ \\
\hline $\begin{array}{l}\text { When I went to U.S.A. The day I went to U.S.A was the best treat } \\
\text { of my life... first I went to miami, I felt very happy and I was so } \\
\text { scare because I didn't know how talk english at that time, but yes, } \\
\text { that was my dream when I had } 7 \text { years old. } 5 \text { or } 7 \text { days later I went } \\
\text { to Orlando and I felt very good because I went to a lot of parts like } \\
\text { universal, that was fantastic because in that park I saw the actors } \\
\text { of the movie "Transformers" and at that time I like that movie a lot. } \\
\text { I saw a lot of funny things. But, that was not the best, the best was } \\
\text { when I went to Disney in Orlando and I saw iMicky Mouse! that } \\
\text { was my dream at that time, because in that time, I all time saw } \\
\text { the program Micky Mouse and also I saw minnie and all of them. } \\
\text { Then, } 5 \text { or } 8 \text { days later, I went to the famous Empire State, and I } \\
\text { learn that in the Empire State was recorted the movie "King Kong". } \\
\text { Finally I learn a lot of things and I comeback to Bogota. }\end{array}$ & $\begin{array}{l}\text { MAIN PARAGRAPH, } \\
\text { FINAL VERSION } \\
\text { Excellent structure. } \\
\text { Includes a good topic } \\
\text { sentence. Supporting } \\
\text { ideas are connected } \\
\text { to the main idea. Weak } \\
\text { concluding sentence } \\
\text { for it does not refer } \\
\text { to the main topic. } \\
\text { Corrected most of } \\
\text { the errors related to } \\
\text { capitalisation. }\end{array}$ \\
\hline $\begin{array}{l}\text { Scare Story } \\
\text { The day I were alone in my house at night was the bad day of my } \\
\text { life... I was in my room listen some music, and I felt that someone } \\
\text { was walking, but in the last floor, so I went to the last floor and } \\
\text { nothing was there but, the windows was moving, I get closer to } \\
\text { the window and a hand fall down, I get scared but also curous, } \\
\text { so I open the window and I discover that was a very weird thing, } \\
\text { I looks like a very big spider, but I get close to that thing and also } \\
\text { I touch it, but were like a rock, that thing not move. Then I went } \\
\text { to my room and I sleep, but when I woke up, I was in a room with } \\
\text { weird animals and I get scare but a lot; there was a door, I open } \\
\text { the door and I discover that my family was doing to me a joke. We } \\
\text { laught a lot of time and then we start to talk how they do the joke. }\end{array}$ & $\begin{array}{l}\text { SESSION 6, EXTRA } \\
\text { PARAGRAPH EXcellent } \\
\text { structure with a clear } \\
\text { topic sentence, } \\
\text { supporting ideas for } \\
\text { the main idea and a } \\
\text { connected concluding } \\
\text { sentence. Although } \\
\text { some errors related } \\
\text { to the use of past } \\
\text { verbs are present, } \\
\text { the participant shows } \\
\text { a very good use of } \\
\text { language. }\end{array}$ \\
\hline
\end{tabular}

In these three paragraphs, the structure (topic sentence, supporting ideas, and concluding sentence) is evident, even in the draft version. This participant has a very good command of English language, as commented by the researcher, in spite of the mistakes made in the three versions, and this fact helped the participant to succeed in writing well-structured paragraphs. In the draft and final version, the concluding sentence was weak, for it did not clearly refer to the main topic affecting somehow text coherence, and it did not fulfill its objective of wrapping the topic up or summarizing it; nevertheless, it is clear that the participant attempted to do so, which shows awareness of the paragraph structure. This was the case of most of the participants who attempted to write their paragraphs following the mentioned structure, making them look well-structured in spite of the weaknesses present (e.g., grammar, spelling, punctuation, coherence).

It is worth noting that participants had to write the extra paragraph in 40 minutes (session 6) due to external factors related to endof-year school activities. For this reason, they did not get enough time 
to plan their paragraph, let alone to revise and edit it effectively. In this sense, participants' realization of narrative paragraph structure was evident, for most of them managed to include the topic sentence, supporting ideas, and concluding sentence connected to personal narrative features such as first person, narration in past, expressing feelings and personal experiences, among others. This aspect reveals that the process-genre approach provided them with the necessary tools and steps to produce acceptable pieces of writing in the future.

Finally, the genre made the writing and assimilation of structure easier, for participants had to write about a topic they knew very well, that is, their own experience. The process-genre approach then provided them with tools to organize their ideas about their experience so that they could fit into a well-structured narrative paragraph. Therefore, genre constitutes a cornerstone in the process of writing, moreover in learning to write for this aspect situates the writer on the right path according to the reader's characteristics and contextualizes the writing in accordance with the objective it wants to achieve.

\section{Difficulties with narrative paragraph structure}

At the beginning of the implementation, some participants were having difficulties related to parts of the paragraph. The terminology was perhaps ambiguous. It was after they were exposed to narrative paragraph models that they grasped the nature of the parts of paragraph structure.

The main difficulty, however, had to do with some participants' attitude towards continuously working on organizing and editing their paragraph. They had to develop ideas to further sequencing them into organization patterns (paragraph structure) and, simultaneously, had to pay attention to language aspects such as grammar, spelling, punctuation, and capitalization. Since the nature of the process-genre approach lies in constantly revising one's own writing compared to specific models in an attempt to improve it repeatedly until the final version is done, some of these young participants must have found this lengthy process as "endless" and, therefore, meaningless. They lost interest and decided to comply with the task submission without putting much effort in the process. This difficulty was evidenced in some of their perceptions as well as some of their artifacts shown in Excerpts 8-9. 
Interviewer: How did you find the writing course workshops? Explain

P4: "Some of them were a bit lengthy, but still we learned a lot."

P11: "It was fun, but a bit lengthy."

\section{Interviewer: What was the most difficult for you when writing the paragraph? Why?}

P10: "I think writing the paragraph was tough because, for example, you wrote something, but then you had to do something else, then you had to refine, then it happened that words were not enough; thus, refining and writing the topic sentence and ideas turned out to be very difficult."

Excerpt 9. Artifacts: draft, final version and extra paragraph, Participant 11

\begin{tabular}{|l|}
\hline \multicolumn{1}{|c|}{ P11 } \\
\hline Picilago \\
The happiest day of my life was \\
when I go to picilago. I go to the zoo \\
of picilago I see fishes, chiguiros, \\
cocodriles, ostrics, etc... I enter to the \\
slides only I dont enter to the megaslide \\
because in that moment I has 125 \\
cm and I nedded $130 \mathrm{~cm}$. ah in that \\
moment I has 9 years old, my sisters, \\
my mom and my dad go to. it was \\
awesome I loved.
\end{tabular}

Researcher's comment
MAIN PARAGRAPH, DRAFT

There is a topic sentence. The few supporting ideas are limited to mentioning some aspects of the experience. The concluding sentence is very vague. The paragraph in general is very short and does not provide a deep view on the experience according to the task objective. There are very few errors.

\section{Picilago}

The happiest day of my life was when I go to picilago. That day I go whit my family, that day was awesome. I went to the zoo of picilago is very big and I saw cocodriles, ostrics, fishes, etc. and I enter to the slides only I don't enter to the megaslide because I haved 125 $\mathrm{cm}$ and I nedded $130 \mathrm{~cm}$ to enter to megaslide.

a scare day

When I go to house I saw a zombie. I enter to my room I ran in circles and I saw a ear because the zombie was in the door later I ran to saw the window and was a lot of zombies later I saw that was a joke that do my friends that day I do a joke that I was a ghost and my friends was scares was awesome.

MAIN PARAGRAPH, FINAL VERSION

There are not significant changes compared to the draft version. On the contrary, some parts at the end were omitted and became a setback

\section{SESSION 6, EXTRA PARAGRAPH}

There is no clear topic sentence nor a concluding one. The body of the paragraph is limited to mentioning some information; the paragraph lacks expressiveness. There are few errors related to grammar and punctuation. 
These artifacts show that there was not much effort to improve, especially from the draft to the final version.

\section{Discussion}

The present study aimed at identifying what happens to paragraph writing when the process-genre approach is used with fourth-grade EFL learners. Based on the previously presented results, it is evident that the process-genre approach helped most of these participants to write well-structured paragraphs, for they realised there is a process to write in which they can use a set of strategies to achieve the writing goal. They also realized there are genres, in this case narratives, with specific characteristics that must be considered when planning, revising, and correcting their writing; apart from this, they acknowledged the importance of the audience, which gave an ultimate purpose to their writings. Finally, they realized there is a structure that makes paragraphs clearer for the reader.

First of all, participants became aware of the writing process with prewriting, drafting, revising/editing and publishing (Badger \& White, 2000), in which the narrative genre transversally played a significant role as mentor text to identify language features and structure, and as criteria to revise, edit and assess participants' paragraphs. In this regard, the present study validated previous studies, which showed that the features of a given genre provide a strong sense of direction and purpose to the writing throughout the stages of the writing process (Cuesta \& Rincón, 2010), serving both as models for instruction and tools for assessment (Lee, 2012) and providing explanations of the way language works in social contexts (Setyowati \& Widiati, 2014). At the same time, these participants became aware of the audience/reader as the main purpose for their writing (Hyland, 2003, 2007) and the motivation to constantly correct and improve their paragraphs so that they were clear and interested for their peers (the audience). Previous studies also evidenced this core aspect more related to writing genres in which participants feel more committed to a purposeful writing with a sense of audience (Elshirbini, 2013; Tuyen et al., 2016; Voon Foo, 2007) 
for whom they make efforts to communicate clear and interesting ideas in their writings (Dirgeyasa, 2016; Handayani \& Siregar, 2013).

Secondly, participants benefited from a set of writing strategies throughout the stages of the process-genre approach, Students used these strategies to analyse narratives, plan their paragraphs, organize their ideas into the paragraph structure (topic sentence, supporting ideas, and concluding sentence), revise for identifying language and structure problems based on narrative samples and a narrative checklist, correct mistakes related to language and structure based on same narrative tools and, subsequently, publish their final version. Correspondingly, previous studies accounted for the benefits process-genre approach brings along related to the development and use of writing strategies in the course of the process to write (Badiaa, 2016; Garnica Olaya \& Torres Burbano, 2015; Gashout, 2014; Rusinovci, 2015; Susser, 1994; Voon Foo, 2007). Some of these strategies were collaborative writing (Fernández Dobao, 2012; Storch, 2005, 2011), planning strategies, organisation of ideas and peer-feedback (Bueno Hernández, 2016), varied organisation patterns according to different purposes (Ahn, 2012), constant revision, correction and evaluation (Alodwan \& Ibnian, 2014; Bayat, 2014) and peer-edition, in which high achiever participants promoted zones of proximal development by providing linguistic scaffolding to empower low achievers; consequently, this led to use thinking strategies such as noticing and explaining when identifying written mistakes (Díaz Galvis, 2010).

Finally, participants realized there is a paragraph structure that has a linguistic as well as a social purpose (i.e., to make a paragraph the clearest possible for the audience); in other words, coherent and cohesive (Harmer, 2004). Likewise, previous studies highlighted the usefulness of the writing process to help learners build well-written (grammatical cohesion) and well-structured paragraphs in an attempt to make them comprehensible for the purpose of the corresponding tasks (Bueno Hernández, 2016; Rodríguez Espinosa, 2014).

The main constraint of the study was related to time, for it was limited to effectively cover input, instruction, practice, and production in the six sessions of the implementation of the process-genre approach. In addition, the school schedule and unplanned end-of-year activities affected the pace of the implementation sessions. Finally, 
there were some difficulties related to some participants' attitude towards the whole process, which they considered very lengthy, and the need for more instruction and practice on punctuation, as this was taken for granted it somehow affected some of the paragraphs' cohesiveness and coherence.

The researcher recommends conducting studies in which the process-genre approach can be used in a shorter period for achieving specific writing goals at a paragraph or longer composition levels; for example, describing a picture, a person, or a place. This suggestion has to do with the fact that not always do learners have the possibility of spending a great deal of time following a process to write in such a detailed way. The idea is to find ways of using simple and quick writing strategies in every stage of the process-genre approach and see whether participants interiorise the method to use it regularly. On the other hand, little attention was given to punctuation in the present study, which, in the end, affected the paragraphs' cohesiveness and coherence. Therefore, it is recommended to analyse the key role that punctuation plays in text cohesion/coherence and effective instruction and practice for young learners in this regard.

\section{References}

Ahn, H. (2012). Teaching writing skills based on a genre approach to L2 primary school students: An action research. English Language Teaching, 5(2), 2-16. http://doi.org/10.5539/elt.v5n2p2

Alodwan, T., \& Ibnian, S. (2014). The effect of using the process approach to writing on developing university students' essay writing skills in EFL. Review of Arts and Humanities, 3(2), 139-155. Retrieved from http://rah-net.com/journals/rah/Vol_3_No_2_June_2014/11.pdf

Babalola, H. A. (2012). Effects of process-genre based approach on the written English performance of Computer Science students in a Nigerian polytechnic. Journal of Education and Practice, 3(6), 1-6. Retrieved from http://pakacademicsearch.com/pdf-files/edu/413/1-6 Vol 3, No 6 (2012).pdf 
Badger, R., \& White, G. (2000). A process genre approach to teaching writing. ELT Journal, 54(2), 153-160. http://doi.org/https://doi.org/10.1093/ elt/54.2.153

Badiaa, A. (2016). The role of the process approach to improve EFL learners' writing skill: The case of first year master students of English at Biskra University (Master's thesis). Retrieved from http://dspace.univ-biskra. dz:8080/jspui/handle/123456789/8582

Bayat, N. (2014). The effect of the process-based writing approach on writing success and anxiety. Educational Sciences: Theory \& Practice, 14(3), 1133-1141. http://doi.org/10.12738/estp.2014.3.1720

Bolitho, R., Carter, R., Hughes, R., Ivanič, R., Masuhara, H., \& Tomlinson, B. (2003). Ten questions about language awareness. ELT Journal, 57(3), 251-259. http://doi.org/https://doi.org/10.1093/elt/57.3.251

Bueno, Y. A. (2016). Thinking, crafting, and commenting: An approach to improuing paragraph structure writing (Master's thesis). Retrieved from http:// intellectum.unisabana.edu.co/handle/10818/24231

Burns, A. (2010). Doing action research in English language teaching: A guide for practitioners. New York, NY: Routledge.

Byrne, D. (1993). Teaching writing skills. London, England: Longman.

Chang, W., \& Szanajda, A. B. (2016). How computer technology transforms writing performance: An integration of the process/genre approach and blogs in EFL writing courses. International Journal for 21st Century Education, 3, 169-185. Retrieved from https://www.uco.es/servicios/ ucopress/ojs/index.php/ij21ce/article/view/5715/5378

Chen, Y. S., \& Su, S. W. (2012). A genre-based approach to teaching EFL summary writing. ELT Journal, 66(2), 184-192. http://doi.org/10.1093/ elt/ccr061

Corbin, J., \& Strauss, A. (2008). Basics of qualitative research: Grounded theory procedures and techniques (3rd ed.). Thousand Oaks, CA: SAGE.

Council of Europe. (2001). Common European framework of reference for languages: Learning, teaching, assessment. Strasbourg, France: Cambridge University Press. Retrieved from http://www.coe.int/t/dg4/linguistic/ Source/Framework_EN.pdf

Cuesta, L., \& Rincón, S. (2010). Short story student-writers: Active roles in writing through the use of e-portfolio dossier. Colombian Applied Linguistics Journal, 12(1), 99-115. Retrieved from http://revistas.udistrital.edu.co/ojs/index.php/calj/article/view/94/144 
Díaz, N. M. (2010). Peer-editing: A strategic source in EFL students' writing process. Colombian Applied Linguistics Journal, 12(1), 85-98. Retrieved from http://revistas.udistrital.edu.co/ojs/index.php/calj/article/ view/93/142

Dirgeyasa, W. (2016). Genre-based approach: What and how to teach and to learn writing. English Language Teaching, 9(9), 45-51. http://doi. org/10.5539/elt.v9n9p45

Elshirbini, I. I. (2013). The effect of the genre-based approach to teaching writing on the EFL Al-Azhr secondary students' writing skills and their attitudes towards writing (Doctoral dissertation). Retrieved from https://eric. ed.gov/?id=ED539137

Fernández, A. (2012). Collaborative writing tasks in the L2 classroom: Comparing group, pair, and individual work. Journal of Second Language Writing, 21, 40-58. http://doi.org/10.1016/j.jslw.2011.12.002

Firkins, A., Forey, G., \& Sengupta, S. (2007). Teaching writing to low proficiency EFL students. ELT Journal, 61(4), 341-352. http://doi. org/10.1093/elt/ccm052

Garnica, V. Y., \& Torres, M. P. (2015). An approximation to writing process through the implementation of a process-genre approach in a blended learning environment (Master's thesis). Retrieved from http://intellectum. unisabana.edu.co/handle/10818/17456

Gashout, M. (2014). Incorporating the facilitative feedback strategies together with the process approach to improve students' writing. International Journal of Education and Research, 2(10), 637-646. Retrieved from http://www.ijern.com/journal/2014/October-2014/51.pdf

Greenwood, D. (Ed.). (1999). Action research: From practice to writing in an international action research developmental program. Philadelphia, PE: John Benjamins Publishing Company.

Handayani, S. W., \& Siregar, M. (2013). Improving students' writing achievement through the process genre approach. Journal of English Language Teaching of FBS Unimed, 2(2), 1-12. Retrieved from http://jurnal.unimed.ac.id/2012/index.php/eltu/article/view/644/455

Harmer, J. (2004). How to teach writing. London, England: Longman.

Hinkel, E. (2006). Current perspectives on teaching the four skills. TESOL Quarterly, 40(1), 109-131. Retrieved from http://www.jstor.org/stable/40264513 
Horowitz, D. (1986). Process, not product: Less than meets the eye. TESOL Quarterly, 20(1), 141-144. Retrieved from http://www.jstor.org/stable/3586397

Hyland, K. (2003). Genre-based pedagogies: A social response to process. Journal of Second Language Writing, 12(1), 17-29. http://doi.org/10.1016/ S1060-3743(02)00124-8

Hyland, K. (2007). Genre pedagogy: Language, literacy and L2 writing instruction. Journal of Second Language Writing, 16, 148-164. http://doi. org/10.1016/j.jslw.2007.07.005

Hyland, K. (2009). Teaching and researching writing (2nd ed.). Harlow, England: Pearson Education Limited.

Lee, I. (2012). Genre-based teaching and assessment in secondary English classrooms. English Teaching: Practice and Critique, 11(4), 120-136. Retrieved from http://education.waikato.ac.nz/research/files/etpc/ files/2012v11n4art8.pdf

McMillan, J., \& Schumacher, S. (2010). Research in education (7th Ed.). Upper Saddle River, NJ: Pearson.

O'Malley, J. M., \& Chamot, A. U. (1990). Learning strategies in second language acquisition. Retrieved from http://ebooks.cambridge.org/ebook.jsf?bid=CBO9781139524490

Porto, M. (2001). Cooperative writing response groups and self-evaluation. ELT Journal, 55(1), 38-46. http://doi.org/https://doi.org/10.1093/ elt/55.1.38

Richards, J., \& Schmidt, R. (2002). Longman dictionary of language teaching and applied linguistics ( $3^{\text {rd }}$ Ed.). London, England: Pearson Education.

Rodríguez, M. C. (2014). The impact of collaborative writing on grammatical cohesion in descriptive paragraph writing in a group of A2 EFL seventh grade learners (Master's thesis). Retrieved from http://intellectum. unisabana.edu.co/handle/10818/10753

Rusinovci, X. (2015). Teaching writing through process-genre based approach. US-China Education Review A, 5(10), 699-705. http://doi. org/10.17265/2161-623X/2015.10.006

Setyowati, L., \& Widiati, U. (2014). Integrating environmental education into a genre-based EFL writing class. English Teaching Forum, 4, 20-27. Retrieved from http://files.eric.ed.gov/fulltext/EJ1050251.pdf 
Storch, N. (2005). Collaborative writing: Product, process, and students' reflections. Journal of Second Language Writing, 14(1), 153-173. http://doi. org/10.1016/j.jslw.2005.05.002

Storch, N. (2011). Collaborative writing in L2 contexts: Processes, outcomes, and future directions. Annual Review of Applied Linguistics, 31, 275-288. http://doi.org/10.1017/S0267190511000079

Susser, B. (1994). Process approaches in ESL/EFL writing instruction. Journal of Second Language Writing, 3(1), 31-47. http://doi.org/10.1016/10603743(94)90004-3

Tribble, C. (1996). Writing. Oxford, England: Oxford University Press.

Tuyen, K. T., Osman, S. B., Dan, T. C., \& Ahmad, N. (2016). Developing research paper writing programs for EFL/ESL undergraduate students using process genre approach. Higher Education Studies, 6(2), 19-29. http://doi.org/10.5539/hes.v6n2p19

Voon, T. (2007). The effects of the process-genre approach to writing instruction on the expository essays of ESL students in a Malaysian secondary school (Unpublished doctoral dissertation). Universiti Sains Malaysia, Penang, Malaysia.

Yang, Y. (2016). Teaching Chinese college ESL writing: A genre-based approach. English Language Teaching, 9(9), 36-44. http://doi.org/10.5539/ elt.v9n9p36

Yate, Y. Y., Saenz, L. F., Bermeo, J. A., \& Castañeda, A. F. (2013). The role of collaborative work in the development of elementary students' writing skills. Profile, 15(1), 11-25. Retrieved from http://www.scielo.org.co/ pdf/prf/v15n1/v15n1a02.pdf 